\title{
LITERATUR REVIEW: PENGARUH REBUSAN DAUN SIRIH TERHADAP PENYEMBUHAN LUKA PERINEUM PADA IBU NIFAS
} Ina Inayatul Milah

Universitas Islam Sultan Agung, Indonesia

E-mail: inayatul.milah@std.unissula.ac.id

\section{Diterima:}

06 November

2021

Direvisi:

10 November

2021

Disetujui:

15 November

2021

\section{Abstrak}

Infeksi post partum merupakan penyebab kematian ibu di Indonesia. Infeksi terbanyak pada ibu post partum yaitu infeksi luka perineum. Perawatan luka perineum merupakan salah satu faktor terjadinya infeksi yang akan memperlambat penyembuhan luka perineum. Penggunaan rebusan daun sirih sebagai pengobatan alternatif untuk mempercepat penyembuhan luka perineum. Literatur nasional ditelusuri melalui sarana media elektronik dengan penuntun kata kunci. Artikel terseleksi sejumlah 6 artikel nasional. yang masing-masing mewakili pengaruh rebusan daun sirih terhadap penyembuhan luka perineum. Untuk mengetahui pengaruh rebusan daun sirih terhadap penyembuhan luka perineum pada Ibu nifas. Adanya perbedaan lama penyembuhan luka perineum pada responden dengan pemberian perlakuan yang sama. Daun sirih merupakan tanaman yang sering digunakan sebagai obat tradisional yang meliliki manfaat sebagai antiseptik kandungan karvakrol bermanfaat untuk keputihan dan pencegahan infeksi. Simpulan berdasarkan analisa yang telah dilakukan adalah penggunaan rebusan daun sirih pada luka perineum efektif untuk mempercepat penyembuhan luka perineum.

Kata kunci: Luka perineum, daun sirih, post partum

Abstract
Post partum infection is a cause of maternal death in
Indonesia. The most common infection in post partum
mothers is perineal wound infection. Perineal wound care
is one factor in the occurrence of infection that will slow
the healing of perineal wounds. The use of betel leaf
decoction as an alternative treatment for perineal wound
healing. National literature through electronic media with
keyword guidance. The number of selected articles is 6
national articles. each of which represents the effect of
betel leaf decoction on perineal wound healing. Objective:
to determine the effect of betel leaf decoction on perineal
wound healing in postpartum women. There is a difference
in the duration of perineal wound healing in respondents
by offering the same treatment. Betel leaf is a plant that is
often used as a traditional medicine which is useful as an
antiseptic. It contains carvacrol which is useful for vaginal
discharge and prevention of infection. The conclusion
based on the analysis carried out is that the use of betel


leaf decoction on perineal wounds is effective in accelerating the healing of perineal wounds.

Keywords: Perineal wound, betel leaf, post partum

\section{Pendahuluan}

Infeksi postpartum merupakan urutan kedua penyebab kematian ibu di Indonesia setelah perdarahan. Angka Kematian Ibu dikenal sejak dahulu sampai sekarang tidak berubah banyak (Yuliaswati, 2018). Menurut Who Angka Kematian Ibu (AKI) adalah kematian pada masa kehailan dan masa nifas atau dalam 42 hari pertama pasca melahirkan. AKI merupakan parameter untuk melihat keberhasilan upaya kesehatan pada ibu. Diperkirakan 303.000 wanita meninggal pada tahun 2015 terjadi pada masa selaa dan setelah kehamilan, dan persalian (Kemenkes RI, 2019). penyebab AKI di Indonesia yaitu perdarahan, preeklamsi dan eklapsi, infeksi. Penyebab utama pada ibu bersalin adalah. Faktor penyebab terjadinya infeksi nifas dapat berasal dari robekan jalan lahir pada jalan lahir yang merupakan tempat masuknya mikroorganisme (Sari, 2017). Perawatan luka perineum yang kurang baik dapat menyebabkan terjadinya infeksi yang akan mempelambat proses penyembuhan luka perineum.

Fisiologi penyembuhan luka menurut (Suzzane \& Smelter, 2002) terdapat tiga fase pertama fase inflamasi. Luka akan mengalami respon vaskuler dan seluler. Pada fase ini luka akan terlihat ada pembengkakan dan kemerahan, hal ini terhadi karena terjadi penggumpalan darah yang akan mengeluarkan zat kimia. fase kedua yaitu fase proliferative dimana terjadi Fibroblas memperbanyak diri dan membentuk jaring-jaring untuk sel-sel yang bermigrasi yang akan menjadi sumber nutrisi bagi jaringan granulasi yang baru, fase ini berlangsung selama 3-5 hari, dan fase yang ketiga yaitu fase matutrisi adalah fase dimana Jaringan parut tampak lebih besar. Fase ini berlangsung selama lebih dari lima hari sampai berbulan-bulan. Cepat lambatnya penyembuhan tiap orang berbeda beda tergantung faktor yang memengaruhinya.

Terdapat beberapa faktor-faktor yang menpengaruhi penyembuhan luka adalah faktor lokal yang terdiri dari praktek perawatan luka, personal hygiene, infeksi, hipovelemia dan adanya benda asing. Sedangkan faktor umum terdiri dari usia, nutrisi, anemia, steroid, sepsis, diabetes dan obat-obatan (Eka, 2013).

Perawatan perineum terdiri dari tiga teknik yaitu teknik dengan memakai antiseptik, tanpa antiseptik dan cara tradisional. Cara trsdisional yaitu dengan menggunakan rebusan sirih sebagai vulva hygiene. Daun sirih (Piper Betle) yaitu merupakan tanaman asli Indonesia. Daun sirih mempunyai kandungan kimia yang berefek sebagai obat antiseptik dan antibakteri, selain itu daun siri juga mengandung bahan kimia sebagai bahan anti inflamasi yang baik digunakan pada ibu dengan luka khususnya pada luka perineum yang dapat membantu mempercepat proses penyembuhan luka perineum.

Banyak Ibu nifas yang menggunakan araebusan daun sirih merah sebagai pengganti betadine karena mengandung zat yang berkhasiat untuk mengobati luka. perbedaan lama penyembuhan, tanda infeksi, nyeri luka perenium dengan menggunakan daun sirih merah $2 \mathrm{x}$ /hari, ekstrak daun sirih merah $1 \mathrm{x} /$ hari dibandingkan dengan Penggunaan Povidone Iodine 10\%. (Stianto, Peristiowati, \& Farida, 2018). Sejalan Dengan Penelitian (Komunitas Et Al., 2020) Terdapat Pengaruh Pemberian Rebusan 
Daun Sirih Merah (Piper Crocatum) Yang Signifikan Terhadap Penyembuhan Luka Perineum Pada Ibu Postpartum Di Desa Tanjung Jati Kecaatan Binai Kabupaten Langkat Dengan P-Value 0,001. Penyembuhan Luka Perineum Pada Kelompok Kontrol Dengan Rerata 5,28 \pm Sd 0,958 Dengan Nilai Min-Max (3-6) Sedangkan Pada Kelompok Intervensi Diberikan Sirih Merah Dengan Rerata Penyembuhan Luka Perineum 3.00 $\pm \mathrm{Sd}$ 1,372 Dengan Min-Max (2-5). Dikembangkan Lagi Dengan Penelitian (Darulis, Kundaryanti, \& Novelia, 2021) Menyebutkan Air Rebusan Daun Sirih Dapat Digunakan Sebagai Alternatif Untuk Mempercepat Penyembuhan Luka Perineum Pada Ibu Nifas. Selain Itu Perlu Adanya Peran Tenaga Kesehatan Khususnya Bidan Dalam Memberikan Edukasi Kepada Ibu Nifas Untuk Meningkatkan Personal Hygiene Sebagai Upaya Penyembuhan Luka Perineum Dan Mencegah Terjadinya Infeksi. Dengan Demikian, Akan Meningkatkan Kesehatan Ibu.

\section{Metode Penelitian}

Penelitian ini dilakukan pencarian literatur melalui media, google scholar, BioMed Central, dan WHO regional databases. Kata kunci yang dipakai untuk penelusuran literatur yaitu "Effectiveness Of Giving Betel Leaf Decoction On Perineal Wound Healing". Cara yang digunakan dalam mencari artikel menggunakan bahasa Inggris dan Indonesia yang relevan dengan topik Artikel yang diperoleh untuk review sebanyak 6 artikel nasional.

Artikel penelitian yang diteliti oleh (Sitepu, Hutabarat, \& Natalia, 2020) yang berjudul "Pengaruh Pemberian Rebusan Daun Sirih Hijau Terhadap Penyembuhan Luka Perinium Pada Ibu Post Partum". Metode penelitian yang digunakan adalah pra eksperimen dengan menggunakan desain pretest and posttest. Penelitian dilakukan di klinik pera simalingkar, Medan pada tahun 2019 dengan sampel dalam penelitian ini 31 responden. Derajat penyembuhan luka perineum sebelum diberikan rebusan daun sirih hijau pada ibu post partum didapat hasil bahwa mayoritas derajat 0 sebanyak 16 orang $(51,6 \%)$ sedangkan deraajat penyembuhan luka perineum sesudah diberikan rebusan daun sirih hijau pada ibu post partum bahwa mayoritas derajat $0(83,9 \%)$. p-value $0,018<\alpha$ 0,05 maka Ho ditolak dan Ha diterima yang menunjukan ada pengaruh pemerian air rebusan daun sisih hijau terhadap penembuhan luka perineum

Artikel penelitian yang dilakukan oleh (Rostika, Choirunissa, \& Rifiana, 2020) yang berjudul "Pengaruh Pemberian Rebusan Daun Sirih Merah Terhadap Waktu Penyembuhan Luka Perineum di Klinik Aster Kabupaten Karawang Jawa Barat" Penelitian quasy eksperimen desain posttest-only control group design. Ada 30 sampel dalam penelitian ini, 15 kelompok eksperimen dan 15 kelompok kontrol. Rebusan daun sirih merah diberikan pada ibu dengan luka perineum pada pagi, siang dan sore hari untuk mempercepat penyembuhan luka perineum. Rata rata penyembuhan luka perineum setelah diberikan rebusan daun sirih merah yaitu 5,80 hari. Terdapat pengaruh pemberian rebusan dau sirih merah padaterhadap waktu penyembuhan luka perineum di Klinik Aster Kabupaten Karawang Jawa Barat

Artikel penelitian yang dilakukan oleh (Siregar, Nazara, Sinaga, Keperawatan, \& Kebidanan, 2020) yang berjudul "Efektivitas Rebusan Daun Sirih Merah Terhadap Penyembuhan Luka Perineum" Metode penelitian ini bersifat kuantitatif analitik observasional dengan jenis desain penelitian ini menggunakan metode quasi eksperimental dengan design pretest posttest one grup design. Penelitian dilakukan pada tanggal 10 agustus s/d 25 agustus 2020 dengan sampel sebanyak 30 orang dengan menggunakan teknik total Sampling. Rebusan daun sirih digunakan 4x sehari sebanyak 500cc sebagai Vulva hygiene dengan cara pembuatan 20 lembar sirih direbus selama 10 menit pada suhu $\mathrm{m}$ suhu $36^{\circ} \mathrm{C}$ Hasil penelitian didapatkan nilai $\mathrm{p}$-value $=0.000(\mathrm{p}<0.05)$ 
menunjukan ada pengaruh rebusan daun sirih merah terhadap penyembuhan luka perineum ibi post partum.

Artikel penelitian yang dilakukan oleh (Yuliaswati, 2018) yang berjudul "Upaya Mempercepat Penyembuhan Luka Perineum Melalui Penggunaan Air Rebusan Sirih Hijau" metode penelitian Quasi eksperimen dengan pendekatan Kohort Prospekti. lama penyembuhan luka perineum pada kelompok eksperimen lebih cepat dibandingkan dengan kelompok kontrol. Pada penelitian ini didapatkan nilai $p$-value $==0,010(p<0,05)$, yang artinya terdapat pengaruh rebusan daun sirih hijau terhadap penyembuhan luka perineum.

Artikel penelitian oleh (Komunitas et al., 2020) yang berjudul "Pengaruh Pemberian Rebusan Daun Sirih Merah (Piper Crocatum) Terhadap Penyembuhan Luka Perineum pada Ibu Postpartum di Desa Tanjung Jati Kecamatan Binjai Kabupaten Langkat" Metode Penelitian Yaitu Quasi Eksperimental, penelitian dilakukan pada bulan April-Juli 2020. Terdapat kelompok kontrol dan eksperimen. Kelompok kontrol sebanyak 18 orang dan kelompok sampel sebanyak 18 orang diberikan rebusan daun sirih hijau sebanyak 4-5 lembar selama 7 hari. ada perbedaan yang bermakna (p- value 0,001) lama penyembuhan antara kelompok kontol dan kelompok eksperimen. lama penyembuhan pada kelompok kontrol 5,28 $\pm 0,958$ dengan Min-Max 3-6 hari, sedangkan pada kelompok intervensi dengan rerata lama penyembuhan 3,00 1,372 dengan Min-Max 2-5. Dapat ditarik kesimpulan ada pengaruh pemberian rebusan daun sirih hijau terhadap penyembuhan luka perineum.

Artikel penelitian oleh (Wanti \& Sitanggang, 2018) yang berjudul "Pengaruh Penggunaan Rebusan Air Daun Sirih Terhadap Lama Penyembuhan Luka Perineum Pada Ibu Postpartum Di Rs. Sariningsih Tahun 2017" Penelitian ini menggunakan quasiExperiment dengan rancangan Posttes Only Control Group. Sebanyak 30 sampel ibu postpartum, 15 sampel kelompok perlakuan dan 15 sampel kelompok kontrol. Lamanya penyembuhan luka pada kelompok perlakuan yaitu $<5$ hari sedangkan lama penyembuhan kelompok kontrol $\leq 5$ hari. Nilai $p$ value 0.000 . Ada pengaruh penggunaan rebusan air daun sirih terhadap lama penyembuhan luka perineum pada ibu postpartum.

\section{Hasil dan Pembahasan}

Berdasarkan hasil literature review yang telah dipaparkan Adanya perbedaan lama penyembuhan luka perineum pada responden prilaku dan control . rata rata responden membutuhkan waktu $\leq 5$ hari untuk penyembuhan luka perineum. Rebusan daun sirih diberikan pada pagi, siang dan sore hari kepada kelompok perilaku. air rebusan daun sirih yang mempunyai sifat antiseptik sehingga dapat mempercepat penyembuhan luka perineum pada ibu post partum.

Perawatan perineum adalah upaya pencegahan infeski pada wanita yang habis melahirkan dengan cara-cara menjaga kebersihan antara lubang dubur dan bagian alat kelamin luar agar memberikan pemenuhan kebutuhan rasa nyaman (Kumalasari, 2015). perawatan luka perineum merupaka salah satu cara untuk mencegah terjadinya infeksi masa nifas. Perawatan dilakukan dengan teknik antiseptik dan non antiseptik. Selain itu untuk beberapa masyarakat melakuakan teknik sederhana untuk merawat luka perineum dengan cara cebok dengan rebusan daun sirih yang bertujuan untuk menghilangkan bau amis dan untuk mempercepat penyembuhan luka perineum. Penggunaan rebusan daun sirih sudah dikenal sejak dahulu dan dilakukan secara turun temurun karena diperacaya sebagai antiseptik. Daun sirih sangat digemari masyarakat selain manfaatnya yang banyak, daun sirih juga mudah didapatkan, harga terjangkau dan memiliki efek samping seminimal mungkin tidak seperti penggunaan obat kimia. 
Daun sirih merupakan tanaman yang sering digunakan sebagai obat tradisional. Ada beragam kandungan yang sangat merupakan antara lain katan ejakulasi dini, membasmi jamur Candida albicans, dan Daunnya mengandung eugenol yang mampu meredakan nyeri pada luka. Sedangkan kandungan karvakrol bermanfaat untuk keputihan dan pencegahan infeksi. Karena karvakol bersifat disinfektan dan antijamur. mengandung arecoline yang bermanfaat untuk meningkatkan daya fikir dan saraf pusat, meningkatkan gerakan peristaltik. Dengan meningkatnya gerakan peristaltik peredaran dala tubuh menjadi lancar sehingga kandungan oksigen juga menjadi lebih banyak, hal tersebut sangat membantu dala proses penyembuhan luka (Damarini, Eliana, \& Mariati, 2013). Kandungan kimia minyak atsiri dalam daun sirih bermanfaat sebagai antiseptik dan penghilang bau badan seperti, kadinen, kavikol, sineol, eugenol, karvanol dan zat samak. Daun sirih juga bisa digunakan sebagai ramuan penghilang bau badan dala bentuk krim atau dengan diminum. Selain itu, daun sirih juga dapat digunakan untuk menghentikan mimisan atau perdarahan yang berasal dari hidung, dengan cara daun sirih digulung seperti rokok dan dimasukan ke dalam lubang hidung (Widya Arif, 2020). Penelitian ini sejalan dengan penelitian (Ari Kurniarum, 2015) di Bidan Praktek Mandiri Kabupaten Klaten tentang Keefektifan Penyembuhan Luka Perineum Pada Menggunakan Daun Sirih. Dari penelitian tersebut daun sirih terbukti 4 kali lipat lebih cepat menyembuhkan luka perineum dibandingkan dengan penggunaan betadine.

Penelitian lain yang mendukung penelitian penulis adalah penelitian oleh tentang Efektivitas Sirih Merah dalam Perawatan Luka Perineum yang dilakukan di Bidan Praktik Mandiri. Penelitian dilakukan pada bulan Mei-Agaustus 2012. Hasil penelitian daun sirih merah lebih efektif dibandingkan iodine untuk penyembuhan luka perineum. rata-rata lama penyembuhan luka perineum menggunakan sirih merah 2 -3 hari sedangkan pada kelompok obat antiseptik rata-rata lama penyembuhan $5-6$ hari.

\section{Kesimpulan}

Berdasarkan analisa yang telah dilakukan oleh penulis penggunaan rebusan daun sirih pada luka perineum efektif untuk mempercepat penyembuhan luka perineum.

\section{Bibliografi.}

Ari Kurniarum, Anik Kurniawati. (2015). Keefektifan Penyembuhan Luka Perineum pada Ibu Nifas Menggunakan Daun Sirih. Jurnal Terpadu Ilmu Keperawatan, 4(2), 163.

Damarini, Susilo, Eliana, Eliana, \& Mariati, Mariati. (2013a). Efektivitas sirih merah dalam perawatan luka perineum di Bidan praktik mandiri. Kesmas: Jurnal Kesehatan Masyarakat Nasional (National Public Health Journal), 8(1), 39-44.

Darulis, Nursupma Oktavia, Kundaryanti, Rini, \& Novelia, Shinta. (2021). The Effect of Betel Leaf Water Decoction on Perineal Wound Healing among Post Partum Women. 1(2), 2017-2022.

Eka, Putra. (2013). Evolusi Manajemen Luka. Jakarta: Trans Info Media.

Komunitas, Jurnal Kesehatan, Langkat, Binjai Kabupaten, Crocatum, Piper, Penyembuhan, Terhadap, Postpartum, Ibu, \& Jati, Tanjung. (2020). The Effect of Giving Red Betel Leaves ( Piper Crocatum) on Healing of Perineum Woes in Postpartum Women in Desa Tanjung Jati Kecamatan. 6(November), 255-259.

Kumalasari, Intan. (2015). Panduan Praktik Laboratorium dan Kinik Perawatan Antenatal, Intranatal, Postnatal, Bayi Bartu Lahir dan Kontrasepsi. Jakarta: Salemba Medika.

Rostika, Teti, Choirunissa, Rizsa, \& Rifiana, Andi Julia. (2020). Pemberian Penggunaan Air Rebusan Daun Sirih Merah Terhadap Waktu Penyembuhan Luka Perineum Derajat I Dan II di Klinik Aster Kabupaten Karawang. Jurnal Ilmiah Kesehatan, 
12(2), 196-204. https://doi.org/10.37012/jik.v12i2.269

Sari, Linda Ayu Kumala. (2017). Efek Pemberian Nipple Stimulation Terhadap Lama

Kala Ii Pada Ibu Primigravida Di Rsud Ambarawa. Karya Ilmiah, 6(1).

Siregar, Debi Novita, Nazara, Titin Sundari, Sinaga, Morina, Keperawatan, Fakultas, \& Kebidanan, Dan. (2020). Efektivitas Rebusan Daun Sirih Merah Terhadap Penyembuhan Luka Perineum. Jurnal Penelitian Perawat Profesional, 2(4), 425430. Retrieved from http://jurnal.globalhealthsciencegroup.com/index.php/JPPP

Sitepu, Stefani Anastasia, Hutabarat, Vitrilina, \& Natalia, Kristin. (2020). Pengaruh Pemberian Rebusan Daun Sirih Hijau Terhadap Penyembuhan Luka Perinium Pada Ibu Post Partum. Jurnal Kebidanan Kestra (JKK), 2(2), 186-193. Retrieved from https://ejournal.medistra.ac.id/index.php/JKK/article/view/384

Stianto, Mitayakuna, Peristiowati, Yuly, \& Farida, Siti. (2018). The Benefits of Red Betel Leaf Extract for Perineal Wound Healing in BPM Rini District Kediri. Journal for Quality in Public Health, 1(2), 58-66. https://doi.org/10.30994/jqph.v1i2.18

Suzzane, \& Smelter. (2002). Buku Ajar Keperawatan Medikal Bedah. Jakarta: EGC.

Wanti, Dida, \& Sitanggang, Tantri Wenny. (2018). Pengaruh Penggunaan Rebusan Air Daun Sirih Terhadap Lama Penyembuhan Luka Perineum Pada Ibu Postpartum Di Rs. Sariningsih Tahun 2017. Kesehatan STIKes IMC Bintaro, 2.

Widya Arif, Widya. (2020). Uji Daya Hambat Air Rebusan Daun Sirih Hijau (Piper betle L.) Terhadap Pertumbuhan Jamur Candida albicans. Padang: Universitas Perintis Indonesia.

Yuliaswati, Enny. (2018). Upaya Mempercepat Penyembuhan Luka Perineum Melalui Penggunaan Air Rebusan Sirih Hijau. Indonesian Journal On Medical Science, 5(1), 94-100.

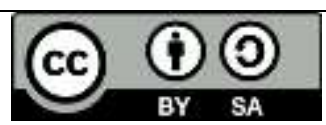

This work is licensed under a Creative Commons Attribution-ShareAlike 4.0 International License. 